\title{
PANCASILA SEBAGAI REFLEKSI KARAKTER BANGSA DAN AKTUALISASINYA DALAM MENGHADAPI FENOMENA HOAX
}

\author{
Muhammad Aziz Zaelani, Wahyu Beny Mukti Setiyawan, Fery Dona; \\ Fakultas Hukum Universitas Islam Batik Surakarta Jl. Agus Salim No. 10 Sondakan Kota \\ Surakarta, Fakultas Ilmu Sosial Universitas Negeri Semarang, \\ Fakultas Syariah Universitas Raden Mas Said Surakarta; \\ E-mail: zael.aziz@gmail.com, dosenbeny@gmail.com, ferydona002@gmail.com
}

\begin{abstract}
Abstrak
Pancasila merupakan norma dasar sebagai sumber dari segala sumber hukum. Sifat abstrak Pancasila menjadi problem-solving yang cepat meresap ke dalam ranah alam konsep pemikiran bangsa menghadapi hoax. Urgensi Pancasila sebagai bangunan utama penyusun Pembukaan Konstitusi, menunjukkan peraturan tidak dapat dipisahkan dengan nilai Pancasila. Penelitian hokum ini normatif dengan menggunakan pendekatan konseptual untuk menemukan aktualisasi Pancasila sebagai problem-solving menghadapi fenomena hoax melalui refleksinya. Hasil penelitian menunjukkan: (i) aktualisasi nilai Pancasila sebagai problem-solving pembentukan karakter bangsa menghadapi fenomena hoax menggunakan etika dari rasa kemanusiaan, sikap jujur, saling peduli, memahami, menghargai, mencintai, tolong menolong; (ii) antinomi hoax dengan karakter bangsa Indonesia dibuktikan ketidaksesuaiannya dengan kepribadian Indonesia diamati dari nilai yang masih eksis dalam masyarakat.
\end{abstract}

Kata Kunci: Aktualisasi, Hoax, Pancasila, Problem-Solving

\section{Abstract}

Pancasila is the ground norm as the source of all sources of law. The abstract nature of Pancasila becomes problem-solving that quickly penetrates to the realm of the nation's concept of thinking in dealing with hoaxes. The urgency of Pancasila as the main building for the compilers of the Preamble to the Constitution shows that regulations cannot be separated from the values of Pancasila. This legal research is normative by using a conceptual approach to find the actualization of Pancasila as problem-solving in dealing with the hoax phenomenon through its reflection. The results of the study show: (i) the actualization of Pancasila values as a problem-solving solution for the formation of the nation's character in dealing with the hoax phenomenon using ethics from a sense of humanity, honesty, caring for each other, understanding, respecting, loving, helping; (ii) the antinomy of hoaxes with the character of the Indonesian nation is proven to be incompatible with the Indonesian personality, observed from the values that still exist in society.

Keywords: Actualization, Hoax, Pancasila, Problem-Solving

\section{PENDAHULUAN}

\section{Latar Belakang}

Perkembangan teknologi serta media sosial, tidak serta merta menampilkan sisi baik. Terdapat konsekuensi logis berupa penyimpangan penggunaan sarana bermedia sehingga cenderung digunakan sebagai arena jajak pemikiran yang dangkal dan terbungkus dalam suatu wadah berupa informasi menyesatkan atau hoax. Fenomena hoax, tidak jarang dimaknai sebagai proses pematangan sosial yang berjalan terus menerus untuk mencapai tingkat kedewasaan pemikiran dalam masyarakat. Hal ini didorong oleh kehidupan publik yang merefleksikan nilai-nilai moralitas suatu bangsa. Semakin jauh kehidupan publik termasuk politisasinya dari landasan etis, maka semakin jauh dengan konsep moralitas yang menjadi tujuan bersama. Hal ini mengakibatkan krisis yang 
meruntuhkan nilai keberadaban, responsibilitas, keadilan serta integritas bangsa. ${ }^{1}$ Hoax atau berita palsu, telah menjadi isu kontroversial dan sangat diperdebatkan dewasa ini. Namun perspektif publik tentang berita palsu direpresentasikan berbeda-beda. Kurangnya kejelasan tentang apa sebenarnya definisi berita palsu tersebut telah menimbulkan bahaya sosial serta hambatan dalam menemukan solusinya. ${ }^{2}$ Ketika hoax menjadi fenomena yang meresahkan, maka hukum harus hadir untuk menertibkan fenomena tersebut. Sebagai hal yang praktis, definisi terhadap hoax terbatas kepada menyebarluaskan pernyataan salah yang disengaja atau tidak disengaja. ${ }^{3}$ Di dunia barat, hal ini dikenal dengan post-truth atau era pasca kebenaran. Post-truth didefinisikan sebagai upaya mengaitkan atau menunjukkan keadaan dimana fakta obyektif kurang berpengaruh dalam membentuk opini publik daripada menarik perhatian emosi dan kepercayaan pribadi. ${ }^{4}$

Hoax menimbulkan permasalahan serius dalam paradigma kehidupan berbangsa, pada dasarnya hal ini merupakan justifikasi belum berhasilnya hukum positif mengemban perannya sebagai sarana mencaapai tertib masyarakat. Hoax dengan berbagai variasi kehadirannya merefleksikan degradasi terhadap nilai kejujuran sebagai salah satu karakter yang dapat ditemukan dalam bangsa Indonesia. Tentu saja hal tersebut menjadi derivasi utama yang akan menimbulkan pertanyaan sudahkah hukum berhasil dalam mengambil perannya dalam mengatasi fenomena hoax. Pada dasarnya Pasal 28F UUD NRI 1945 menyebutkan hak memperoleh informasi: "Setiap orang berhak untuk berkomunikasi dan memperoleh informasi untuk mengembangkan pribadi dan lingkungan sosialnya, serta berhak untuk mencari, memperoleh, memiliki, menyimpan, mengolah, dan menyampaikan informasi dengan segala jenis saluran yang tersedia". Perkembangannya, perkembangan informasi semakin kuat dan dipayungi dengan Undang-Undang Nomor 14 Tahun 2008 tentang Keterbukaan Informasi Publik. Dapat dimaknai hukum membuka kebebasan seluasnya untuk melakukan mobilisasi informasi dalam masyarakat. Namun perlu diperhatikan informasi yang disalahgunakan atau bahkan tidak benar dapat menimbulkan keresahan dalam segala aspek bermasyarakat.

Hukum sebagai sarana penunjang ketertiban, ditantang untuk memposisikan diri sebagai gerbang utama pemenuhan hak masyarakat terhadap informasi yang baik dan benar, dalam tanda kutip tidak menyesatkan. Fenomena ini cenderung digunakan, terutama sebagai bahan pengalihan isu, alat menyerang lawan politik dan bahkan sarana mencari keuntungan dengan menaikkan oplah atau mengkomersialisasikan informasi hoax tersebut, tidak peduli dampak yang akan dihasilkannya. Timbul juga pertanyaan, mengapa dalam konteks ini hukum belum berhasil mengatasi fenomena hoax, dan dewasa

1 Yudi Latif. (2011). Negara Paripurna, Historisitas, Rasionalitas, dan Aktualitas Pancasila. Jakarta: Gramedia Pustaka Utama, h. 49.

2 Mark Verstraete, et. al. (2012). "Identiying and Countering Fake News". Arizona Legal Studies Discussion Paper, 1(2), 17-35.

${ }^{3}$ David O. Klein \& Joshua R. Wueller. (2019). "Fake News: A Legal Perspective". Journal of Internet Law, 28(10), 6-13.

${ }^{4}$ Budi Prayitno. (2017). "Langkah Pemerintah Menangkal Diseminasi Berita Palsu". Jurnal Wacana Kinerja, 20(2), 17-39. 
ini hoax dirasakan semakin marak dan komplek. Hukum ditempatkan sebagai alat saja tanpa menggali pemaknaan lebih mengenai esensi hukum itu sendiri, sehingga dalam perjalanannya, hukum semakin menjauh dari moral.

Penebar hoax, dalam hal ini dapat dijerat pasal dalam KUHP ataupun UndangUndang Nomor 19 Tahun 2016 tentang Perubahan Atas Undang-Undang Nomor 11 Tahun 2008 tentang Informasi dan Transaksi Elektronik (UU ITE). Pemerintah mengambil langkah dalam penanganan hoax, seperti menciptakan regulasi dan sarananya berupa portal, aplikasi aduan, jejaring komunikasi serta pembentukan pasukan siber. ${ }^{5}$ Regulasi yang ada yaitu UU ITE, Permenkominfo Nomor 19 Tahun 2014 tentang Penanganan Situs Internet Bermuatan Negatif, Permenpan Nomor 83 ahun 2012 tentang Pengelolaan Media Sosial Instansi Pemerintah, Instruksi Presiden Nomor 9 Tahun 2015 tentang Pengelolaan Komunikasi Publik. Hal ini merupakan langkah represif negara dalam melakukan fungsinya menciptakan tertib dalam masyarakatnya. Langkah represif tersebut berujung ke wujud law enforcement atau penegakkan hukum bagi pelaku penyebar berita palsu atau hoax. Menurut Jimly Asshiddiqie, penegakkan hukum adalah proses dilakukannya upaya untuk tegaknya atau berfungsinya norma-norma hukum secara nyata sebagai pedoman perilaku dalam lalu lintas dan hubungan-hubungan hukum dalam kehidupan bermasyarakat dan bernegara. Penegakkan hukum dapat dilihat dari segi subyek dan segi obyeknya. ${ }^{6}$ Namun penegakkan hukum tidak mesti berhubungan dengan implementasi pelaksanaan norma hukum tertulis yang dalam hal ini dimaknai sebagai peraturan perundang-undangan.

Soerjono Soekanto, menyatakan penegakan hukum lebih kepada keserasian hubungan antara nilai-nilai yang dijelaskan dalam kaidah-kaidah yang pasti dan berwujud dengan perilaku sebagai rangkaian penjabaran nilai tahap akhir untuk meciptakan, memelihara dan mempertahankan kedamaian pergaulan hidup. Lebih lanjut dikatakan bahwa penegakan hukum bukanlah semata-mata berarti pelaksanaan perundang-undangan walaupun kenyataan di Indonesia kecenderungannya adalah demikian. ${ }^{7}$ Dapat dipahami penegakkan hukum juga termasuk, menurut hemat penulis langkah penjabaran nilai-nilai melalui fungsi aktualisasi terhadap nilai tersebut sehingga dapat menjadi langkah preventif pencegahan hoax.

Negara memerlukan sarana yang bersifat preventif dalam rangka membangun karakter bangsa. Sarana tersebut haruslah memiliki fleksibilitas tinggi serta dapat digunakan di dalam segala aspek kehidupan berbangsa dan bernegara. Pancasila menjelma sebagai sarana kontrol preventif untuk menyokong pembangunan karakter bangsa Indonesia. Keberadaan Pancasila, belakangan ini, sering dinafikan dan hanya sebatas menjadi jargon atau lambang usang. Hakikat Pancasila telah terdegradasi menjadi aspek sepele yang begitu saja dilangkahi keberadaannya. Sejatinya, Pancasila adalah bintang pemandu yang menjadi landasan filosofis, dasar negara serta refleksi jati diri

\footnotetext{
${ }^{5}$ Ibid.

${ }^{6}$ Jimly Asshiddiqie. (2013). "Penegakkan Hukum". Makalah, h. 1-3.

7 Soerjono Soekanto. (1986). Faktor-Faktor yang Mempengaruhi Penegakan Hukum. Jakarta: Rajawali, h. 3.
} 
bangsa Indonesia. Dalam Pancasila mengandung rechtidie, maupun volgeist sebagai bukti kedekatan historis, sosiologis, serta filosofis dengan karakter bangsa Indonesia. Pembentukan karakter bangsa sejatinya didasari oleh penjabaran nilai yang hidup dan lestari dalam bangsa tersebut. Oleh karenannya menggali kembali Pancasila sebagai langkah pembangunan karakter bangsa melalui perenungan yang sistematis dalam wujud aktualisasi nilai Pancasila. Dengan langkah aktualisasi ini diharapkan Pancasila dapat menjadi suatu problem-solving dalam menyelesaikan berbagai permasalahan berbangsa dan bernegara yang dewasa ini salah satunya memunculkan fenomena hoax sebagai wujud permasalahannya.

\section{Rumusan Masalah}

1. Bagaimana aktualisasi nilai Pancasila sebagai problem-solving pembentukan karakter bangsa menghadapi fenomena hoax?

2. Bagaimana antinomi hoax dengan karakter bangsa Indonesia?

\section{METODE PENELITIAN}

Penelitian hukum normatif ini menggunakan pendekatan konseptual untuk menemukan aktualisasi Pancasila sebagai problem-solving menghadapi fenomena hoax melalui refleksi nilai-nilainya.

\section{PEMBAHASAN}

\section{A. Aktualisasi Nilai Pancasila Sebagai Problem-Solving Pembentukan Karakter Bangsa Menghadapi Fenomena Hoax}

Kehadiran hoax merupakan fenomena yang mendampingi perkembangan teknologi informasi sebagai suatu paket tanpa kompromi. Manuel Castells menyatakan transformasi sosial yang sedang terjadi dalam kecepatan tinggi menjelang akhir milenium kedua, merefleksikan pembentukan basis material masyarakat. Kesimpulannya revolusi teknologi, khususnya dalam hal perkembangan teknologi informasi, mempercepat perubahan politik, kultur, ekonomi dan hubungan sosial. ${ }^{8}$ Hal ini ditambah peran media yang tidak terkontrol seperti internet yang kehadirannya bagai membawa dua sisi mata uang. Internet menyediakan kanal komunikasi yang relatif murah, horizontal, tidak gampang dikontrol, dari orang-per-orang menjadi satu-ke-banyak. Internet menyimpan potensi luar biasa sebagai wadah ekspresi hak warga negara yang mengkomunikasikan nilai-nilai manusia. Internet mendekatkan banyak orang dalam sebuah ruang publik. ${ }^{9}$ Maka, diperlukan sinergi melalui aktualisasi Pancasila yang berdimensi abstrak sehingga memudahkan memasuki ruang konsep pikiran masyarakat sebagai problem-solving. Indonesia telah mempunyai norma fundamental yaitu Pancasila yang berisi falsafah dan jiwa kebangsaan Indonesia. Pancasila bersifat norma abstrak dan tidak tertulis namun sebagai landasan fundamental dari seluruh norma di Indonesia. Pancasila juga yang menjadi kerangka pembukaan (preambule) Undang-Undang Dasar Negara Indonesia

\footnotetext{
8 Manuel Castells. (2000). The Information Age: Economy, Society and Culture, Volume I: The Rise of the Network Society. Oxford: Blackwell, h. 27.

${ }^{9} \mathrm{Ibid}, \mathrm{h} .157,164$.
} 
Tahun 1945. Dalam pembukaan tersebut terdapat cita-cita bangsa (rechtsdiie), tujuan bangsa serta norma fundamental bangsa (Pancasila).

Hans Nawiasky dalam die Theorie vom Stufenordnung der rechtsnormen melakukan klasifikasi terhadap bentuk setiap norma dalam tingkatannya masing-masing, sehingga tidak lagi merupakan bentuk pemisahan tingkatan secara general, namun sudah merupakan klasifikasi dari bentuk norma-norma tersebut. Norma fundamental Negara harus ditetapkan terlebih dahulu oleh masyarakat dalam suatu Negara dan merupakan norma yang menjadi tempat bergantungnya norma-norma hukum di bawahnya. Kenyataan diatas mendasari Pancasila sebagai pemaknaan dari Staatsfundfamental Norm tersebut yang secara harfiah menempatkan Pancasila sebagai kesepakatan awal dan tidak membutuhkan validitas lain terhadapnya. Oleh karenannya, Pancasila hidup berbarengan dengan bangsa Indonesia sebagai suatu identitas tak terpisahkan. Undang-Undang Nomor 15 Tahun 2019 tentang Perubahan Atas Undang-Undang Nomor 12 Tahun 2011 tentang Pembentukan Peraturan Perundang-Undangan, menyebutkan Pancasila sebagai sumber dari segala sumber hukum. Konklusinya, sebagai norma abstrak, Pancasila harus menjadi roh dari setiap aturan hukum di Indonesia. Pancasila juga dapat ditempatkan sebagai alat mengelola problem Indonesia, dan keberadaannya harus didasari sebuah fundamen moral. Fundamen moral tersebut adalah Sila Ketuhanan. ${ }^{10}$ Keberadaan Pancasila harus dilekatkan baik dalam hal pembuatan maupun pelaksaanaan aturan hukum.

Upaya mewujudkan Pancasila sebagai sumber nilai adalah dengan dijadikannya nilai-nilai dasarnya menjadi sumber bagi penyusunan norma hukum di Indonesia. Sistem hukum Indonesia, dalam tataran ini bersumber dan berdasar pada Pancasila sebagai norma dasar bernegara.11 Pancasila berkedudukan sebagai "mirip" grundnorm dalam Stufentheorie atau sebagai Staatfundamental norm dalam jenjang hukum di Indonesia. Hukum lebih tepat ditempatkan sebagai validitas yang sejalan dengan moral. Dengan kata lain, moral menjadi koridor penuntun hukum yang diimplementasikan oleh subyek hukum. Moral menjadi penuntun manusia dalam setiap kegiatan hidupnya, yang memberikan kepada kebenaran menurut rasio. Aristoteles menjabarkan inti manusia adalah moral yang rasional, yang memandang kebenaran (theoria, kontemplasi) sebagai keutamaan hidup (summum bonum). ${ }^{12}$ Dalam prosesnya manusia dipandu akal dan moral. Sebelumnya, keyakinan klaim bahwa hukum harus sesuai dengan moral lebih banyak menemui kegagalan untuk dijelaskan, banyak diantaranya yang menggambarkan kebingungan hubungan necessary antara hukum dan moral. Hart juga merefleksikan pengaruh moralitas terhadap hukum (the influence of morality on Law).

Pengesahan secara konstitusional pada 18 Agustus 1945 memberikan proporsi Pancasila sebagai philosophische grondslag, ligatur maupun Leitstar yang secara luas terletak dalam

\footnotetext{
${ }^{10}$ Bernard L. Tanya, et. al. (2010). Pancasila Bingkai Hukum Indonesia. Yogyakarta: Genta Publishing, h. 41.

${ }^{11}$ Mohamad Sinal. (2017). Pancasila Konsensus Bangsa-Bangsa Indonesia. Malang: Madani, h. 12.

12 Bernard L. Tanya. (2011). Penegakkan Hukum dalam terang Etika. Yogyakarta: Genta Publishing, h. 86.
} 
kehidupan kebangsaan dan kenegaraan Indonesia. ${ }^{13}$ Urgensi Pancasila adalah sebagai satu alat pemersatu yang dapat menyatukan Indonesia. Oleh karenannya bangsa Indonesia mempunyai landasan moralitas dan haluan kebangsaan yang jelas dan visioner. Suatu pangkal tolak dan tujuan pengharapan yang penting bagi keberlangsungan dan kejayaan bangsa. ${ }^{14}$ Nilai-nilai yang terkandung dalam Pancasila merupakan sekumpulan nilai yang diangkat dari prinsip nilai yang hidup dan berkembang dalam masyarakat. Nilai-nilai tersebut berupa nilai religius, nilai adat istiadat, kebudayaan dan setelah disahkan menjadi dasar negara, terkandung di dalamnya nilai kenegaraan.15 Pancasila harus menjadi langkah penyelesaian permasalahan bangsa. Dalam hal ini Pancasila diletakkan sebagai ideologi yang berfungsi sebagai problem-solving. Pancasila sebagai problem-solving memposisikan Pancasila sebagai jawaban bagi problem-problem pembangunan bangsa, ketertiban dan menjadi landasan bagi persatuan dan keragaman Indonesia. ${ }^{16} \mathrm{Hal}$ ini membuat Pancasila sebagai pemandu dalam konteks penyelesaian permasalahan berbangsa dan bernegara.

Salah satu bentuk aktualisasi Pancasila dalam menghadapi fenomena hoax yang mengancam perubahan karakter bangsa ke arah negatif, adalah aktualisasi nilai persatuan Indonesia. Dalam hal ini Pancasila meletakkan dasar kebangsaan sebagai simpul persatuan Indonesia. Konsep kebangsaan yang mengekspresikan unity in diversy, diversy in unity dalam simpul Bhineka Tunggal Ika. ${ }^{17}$ Wujud konkretnya adalah menekankan kembali hakikat berkebangsaan secara preventif melalui pendalaman nilai Pancasila di lingkup dunia pendidikan. Satu bangsa adalah satu jiwa (une nation est un ame), satu bangsa adalah satu solidaritas yang besar (une nation est un grand solidarite), disempurnakan dengan suatu pengikat yaitu kemauan untuk hidup bersama (le desir d'etre ensemble), demikian pendapat Ernest Renan yang dikutip Bung Karno.

"Jadi gerombolan manusia, meskipun agamanya berwarna macam-macam, meskipun bahasanya bermacam-macam, meskipun asal turunannya bermacam-macam, asal gerombolan manusia itu mempunyai kehendak untuk hidup bersama, itu adalah bangsa."18

Pemahaman di atas menjadi garda terdepan membangun mentalitas persatuan bangsa yang secara langsung dapat direfleksikan menjadi formula menekan fenomena hoax serta membangun karakter bangsa berwawasan Pancasila. Aktualisasi menjadi langkah kunci membangun karakter bangsa mencegah fenomena hoax. Sasaran dari aktualisasi tersebut dapat ditekankan khususnya dalam tataran dunia akademisi. Sebagai pencipta pribadi yang berilmu, dunia akademik menjadi wadah yang nyata dan tepat mendukung aktualisasi nilai Pancasila. Refleksi yang didapat adalah membangun cendekiawan yang mengerti serta memahami nilai Pancasila sehingga menjadi langkah

\footnotetext{
13 Yudi Latif, Op. Cit., h. 41.

14 Ibid, h. 41.

15 Kaelan. (2002). Filsafat Pancasila, Pandangan Hidup Bangsa Indonesia. Yogyakarta: Paradigma, h. 140.

16 Hendar Putranto. (2016). Ideologi Pancasila Berbasis Multikulturalisme. Jakarta: Mitra Wacana Media, h. 56.

17 Yudi Latif, Op. Cit., h. 369.

18 Ibid, h. 370.
} 
preventif dalam menanggulangi fenomena hoax yang menjadi intrik di dalam masyarakat dewasa ini. Hoax memang merupakan salah satu kebebasan berinformasi yang secara masif digemborkan pasca reformasi. Menjadi bahaya laten jika hoax terus menjadi bagian dari kebudayaan komunikasi modern karena akan menghilangkan obyektifitas suatu informasi, mengesampingkan validitas ataupun sumber kebenaran sebagai tonggak informasi yang baik dan benar.

\section{B. Antinomi Hoax Dengan Karakter Bangsa Indonesia}

Pancasila erat pemaknaannya sebagai hal yang abstrak. Dalam keabstrakan inilah justru dapat diambil nilai-nilai etis sebagai kontrol kuat menghadapi permasalahan. Terlebih kedekatan Pancasila sebagai refleksi dari bangsa Indonesia karena diambil dari nilai-nilai yang hidup di dalamnya. Kedekatan tersebut yang dewasa ini terkikis karena kurangnya pemahaman nilai Pancasila, menjadi konsekuensi logis degradasi pemaknaannya sehingga dirasa dinamika bangsa ini maju tanpa sarana kontrol dalam wadah Pancasila. Oleh karenanya diperlukan penggalian kembali nilai Pancasila sebagai perwujudan usaha mengembalikan karakter bangsa yang berwawasan Pancasila. Hal tersebut dapat diwujudkan melalui fungsi aktualisasi Pancasila yang menjadi bintang pemandu dalam menghadapi dinamika kehidupan berbangsa dan bernegara. Aktualisasi bisa dikatakan sebagai langkah preventif yang akan menjadi tolok ukur memanifestasikan kepribadian dan karakter bangsa dalam langkah konkret berbangsa serta bernegara.

Jangkauan Pancasila dalam menyatukan bangsa sudah jauh melampai yang diharapkan, mengingat Indonesia dalam tataran nusantara diwarisi kondisi pluralisme yang disebabkan oleh perbedaan geografis, menyebabkan perbedaan etnografis, sosiologis serta politis, namun kesemuannya itu dirangkul oleh nilai persatuan dalam Pancasila. Masyarakat yang plural sejatinya berwujud masyarakat yang terdiri atas dua atau lebih elemen atau tatanan sosial yang hidup berdampingan, tetapi tanpa melebur dalam satu unit politik sebagaimana dijelaskan oleh Furnivall ${ }^{19}$. Namun yang terjadi di Indonesia kesemuanya terlebur dalam nilai persatuan Pancasila, sehingga dalam hal ini penulis mendefinisikan nilai persatuan dalam Pancasila sebagai tonggak utama yang menjadi fungsi utama aktualisasi nilai-nilai Pancasila dalam mencegah fenomena hoax yang dikuatirkan dapat merubah karakter bangsa Indonesia ke arah negatif.

Aktualisasi nilai-nilai etis kemanusiaan terlebih dahulu harus mengakar kuat dalam lingkungan pergaulan kebangsaan yang lebih dekat sebelum menjangkau pergaulan dunia yang lebih jauh. ${ }^{20}$ Bhineka Tunggal Ika hadir sebagai kaidah historis pengemban fungsi nilai persatuan Indonesia. Dalam konteks ini, maka Pancasila dimaksudkan untuk mengelola konsepsi kebangsaan yang mengatasi paham golongan dan mengekspresikan persatuan dalam keragaman, dan keragaman dalam persatuan.21 Oleh karenannya

\footnotetext{
19 J. S. Furnivall. Plural Societies, dalam H-D. Evers (Ed.). (1980). Sociology of South-East Asia: Reading on Social Change and Development. Kuala Lumpur: Oxford University Press, h. 29.

${ }^{20}$ Yudi Latif, Op. Cit., h. 44.

${ }^{21} \mathrm{Ibid}$, h. 44.
} 
Pancasila dapat dikatakan suatu terobosan yang mempertemukan kemajemukan masyarakat sebagai pemersatu (ligatur) bangsa Indonesia.

Hoax sejatinya yang merupakan berita tidak jelas baik dalam hal substansi, validitas atau kebenarannya, harus dibuat garis pemisahnya karena tidak sesuai dengan karakter bangsa Indonesia. Pancasila sebagai garis tegas pemisahan tersebut akan menjawab bagaimana antinomi fenomena hoax dengan kepribadian atau karakter bangsa Indonesia. Bangsa ini memiliki Pancasila yang diyakini sejak lama sebagai karakter dan perasan dari jiwa bangsa. Klaim sebagai negara hukum seyogyanya juga merujuk pada norma dasar yang ada pada Pancasila. ${ }^{22}$ Secara sederhana, hoax adalah pemberitaan palsu. Ditujukan untuk mengarahkan publik supaya mempercayai sesuatu tanpa berdasar kepada fakta empirik. Maka, hoax adalah produk yang lahir tanpa kandungan kebenaran dan merupakan anak haram informasi. ${ }^{23}$ Hoax telah menjadi problem besar dalam komunikasi masyarakat, menjadi sebuah lingkaran setan tak berujung, karena karena bisa saja korban dan pelaku hoax adalah orang yang sama. ${ }^{24}$ Hoax akan menjadi senjata mematikan jika digunakan dalam wilayah politik ataupun hal-hal yang menyerempet Suku Agama Ras (SARA). Di sisi ini, rasio masyarakat menjadi terkikis dan tertutupi oleh informasi hoax yang diterima dan menafikan validitasnya. Istilah yang cocok menanggapi fenomena ini adalah: "rumors are carried by haters, spreaded by fools, and accepted by idiots" 25 . Frasa tersebut mendeskripsikan kehilangan mendalam terhadap rasio masyarakat yang mengesampingkan mengecek kembali kebenaran informasi hoax tersebut.

Antinomi juga didapatkan dalam memahami kebebasan berinformasi, namun kenyataannya hoax bukan merupakan refleksi dari bentuk kebebasan tersebut. Kebebasan memandu manusia dalam menentukan pilihan untuk berperilaku berdasarkan nilai-nilai yang diyakininya. Kebebasan harus berlandaskan pada kosmologi bangsa Indonesia yang kontekstual, beragam dan penuh dengan perasaan otentik yaitu berwibawa dan penuh harga diri. Kebebasan tidak dijalankan dengan arogansi, anarkisme, individualistik ataupun membelakangi Pancasila. ${ }^{26}$ Kebebasan penuh dengan "tepo sliro" atau toleransi, empati terhadap sesama. Moralitas kebebasan ditekankan dalam Pancasila yang menjadi bintang pemandu bentuk kebebasan tersebut. Kenyataan refleksi hoax tidak sesuai dengan refleksi kepribadian Indonesia yang dapat diambil dan diamati dari nilai-nilai yang masih eksis dalam masyarakat. Nilai yang dimaksud berkaitan dengan etika sosial dan budaya, yang mana bangsa Indonesia mengedepankan sikap jujur, saling peduli, saling memahami, saling menghargai, saling mencintai, dan saling tolong menolong

22 Any Farida. (2016). Landasan Etis Negara Hukum Indonesia dalam Bingkai Pancasila, dalam Absori. (2016). Cita Hukum Pancasila, Ragam Paradigma Hukum Berkepribadian Indonesia. Sukoharjo: Pustaka Iltizam, h. 132.

23 Firsan Nova. Republika.co.id, 2017. Hoax dan Pudarnya Kejantanan Berpendapat. https://www.republika.co.id/berita/jurnalisme-warga/wacana/17/01/18/ojy8qs336-hoax-danpudarnya-kejantanan-berpendapat?fb_comment_id=1052929848163739_1053084664814924， diunduh Sabtu 18 Desember 2021.

${ }^{24}$ Manuel Castells, Op. Cit., h. 157.

${ }^{25}$ Ibid, h. 136-137.

${ }^{26}$ Ibid. 
diantaranya. Bangsa ini dengan aktualisasi nilai Pancasila harus dapat menghidupkan kembali budaya malu berbuat kesalahan dan semua hal yang bertentangan dengan moral agama dan nilai-nilai lihur budaya bangsa. Konklusinya, perlu dihidupkan lagi budaya keteladanan yang harus dimulai dan diperlihatkan contohnya oleh para pemimpin pada setiap tingkat dan lapisan masyarakat. ${ }^{27}$ Dalam poin ini, penting menempatkan hukum (tertulis) selaras dengan nilai moral. Hukum pada setiap negara modern menunjukkan ribuan poin penuh moralitas yang diterima oleh masyarakat maupun ide-ide moral yang lebih luas. Pengaruh ini kemudian merasuki hukum secara nyata. Banyak hal yang menunjukkan bagaimana hukum mencerminkan moralitas. Hal demikian adalah fakta, yang berarti stabilitas sistem hukum tergantung sebagian pada bentuk kesesuaiannya dengan moral dan keberadaannya harus diakui. ${ }^{28}$ Lalu perlu juga dikritisi bagaimana juga konklusi ini dikaitkan dengan teori yang memisahkan hukum dengan moralitas. Hukum dan moral itu berbeda, hukum diartikan teks undang-undang, sedangkan moral merujuk pada prinsip-prinsip tertinggi tindakan atau perilaku manusia yang baik atau buruk. ${ }^{29}$ Meskipun berbeda, tetapi normative jurisprudence, memandang ada suatu hubungan keterkaitan antara hukum dengan ide-ide moral secara sistematis. Hubungan antara hukum dan moral (conceptual connection between law and morality) polanya sangat ditentukan dari pandangan mengenai sumber hukum termasuk diadopsinya moral kedalam hukum positif.

\section{PENUTUP}

Aktualisasi nilai Pancasila sebagai problem-solving pembentukan karakter bangsa menghadapi fenomena hoax adalah nilai etika dan sosial yang hidup dalam jiwa bangsa Indonesia. Etika ini berasal dari rasa kemanusiaan yang mendalam dengan menampilkan kembali sikap jujur, saling peduli, saling memahami, saling menghargai, saling mencintai, dan tolong menolong diantara sesama manusia dan anak bangsa. Sasaran dari aktualisasi tersebut dapat ditekankan khususnya dalam tataran dunia akademisi. Sebagai pencipta pribadi yang berilmu, dunia akademik menjadi wadah yang nyata dan tepat mendukung aktualisasi nilai Pancasila. Refleksi yang didapat adalah membangun cendekiawan yang mengerti serta memahami nilai Pancasila sehingga menjadi langkah preventif dalam menanggulangi fenomena hoax yang menjadi intrik di dalam masyarakat dewasa ini.

Antinomi hoax dengan karakter bangsa Indonesia dibuktikan dengan refleksi hoax yang tidak sesuai dengan refleksi kepribadian Indonesia yang dapat diambil dan diamati dari nilai-nilai yang masih eksis dalam masyarakat. Nilai yang dimaksud berkaitan dengan etika sosial dan budaya, yang mana bangsa Indonesia mengedepankan sikap jujur, saling peduli, saling memahami, saling menghargai, saling mencintai, dan saling tolong menolong diantaranya. Bangsa ini dengan aktualisasi nilai Pancasila harus dapat

\footnotetext{
27 Mohamad Sinal, Op. Cit., h. 13-14.

28 Ali Safa'at. (2016). Konsep Hukum H. L. A Hart. Jakarta: Konstitusi Press, h. 56.

29 I Dewa Gede Atmadja. (2013). Filsafat Hukum Dimensi Tematis dan Historis. Malang: Setara Press, h. 87 .
} 
menghidupkan kembali budaya malu berbuat kesalahan dan semua hal yang bertentangan dengan moral agama dan nilai-nilai luhur budaya bangsa.

\section{DAFTAR PUSTAKA}

Asshiddiqie, Jimly. (2013). Penegakkan Hukum. Makalah.

Atmadja, I Dewa Gede. (2013). Filsafat Hukum Dimensi Tematis dan Historis. Malang: Setara Press.

Castells, Manuel. (2000). The Information Age: Economy, Society and Culture, Volume I: The Rise of the Network Society. Oxford: Blackwell.

Farida, Any. (2016). Landasan Etis Negara Hukum Indonesia dalam Bingkai Pancasila. dalam Absori. (2016). Cita Hukum Pancasila, Ragam Paradigma Hukum Berkepribadian Indonesia. Sukoharjo: Pustaka Iltizam.

Furnivall, J. S. (1980). Plural Societies. dalam H-D. Evers (Ed.). (1980). Sociology of South-East Asia: Reading on Social Change and Development. Kuala Lumpur: Oxford University Press.

Kaelan. (2002). Filsafat Pancasila, Pandangan Hidup Bangsa Indonesia. Yogyakarta: Paradigma.

L. Tanya, Bernard. (2011). Penegakkan Hukum dalam terang Etika. Yogyakarta: Genta Publishing.

L. Tanya, Bernard, et. al. (2010). Pancasila Bingkai Hukum Indonesia. Yogyakarta: Genta Publishing.

Latif, Yudi. (2011). Negara Paripurna, Historisitas, Rasionalitas, dan Aktualitas Pancasila. Jakarta: Gramedia Pustaka Utama.

Nova, Firsan. (2017). Republika.co.id. Hoax dan Pudarnya Kejantanan Berpendapat. https://www.republika.co.id/berita/jurnalisme-

warga/wacana/17/01/18/ojy8qs336-hoax-dan-pudarnya-kejantananberpendapat?fb_comment_id=1052929848163739_1053084664814924, diunduh Sabtu 18 Desember 2021.

O. Klein, David \& R. Wueller, Joshua. (2019). “Fake News: A Legal Perspective”. Journal of Internet Law, 28(10), 6-13.

Prayitno, Budi. (2017). "Langkah Pemerintah Menangkal Diseminasi Berita Palsu". Jurnal Wacana Kinerja, 20(2), 17-39.

Putranto, Hendar. (2016). Ideologi Pancasila Berbasis Multikulturalisme. Jakarta: Mitra Wacana Media.

Safa'at, Ali. (2016). Konsep Hukum H. L. A Hart. Jakarta: Konstitusi Press.

Sinal, Mohamad. (2017). Pancasila Konsensus Bangsa-Bangsa Indonesia. Malang: Madani.

Soekanto, Soerjono. (1986). Faktor-Faktor yang Mempengaruhi Penegakan Hukum. Jakarta: Rajawali.

Verstraete, Mark, et. al. (2012). "Identiying and Countering Fake News". Arizona Legal Studies Discussion Paper, 1(2), 17-35. 